\title{
ОСОБЛИВОСТІ АКУМУЛЮВАННЯ ВАЖКИХ МЕТАЛІВ \\ ВЕГЕТАТИВНИМИ ОРГАНАМИ СНЕNOPODIUM ALBUM L. В УМОВАХ ТЕХНОГЕННОГО ЗАБРУДНЕННЯ ГРУНТІВ М. ЧЕРКАСИ
}

\section{Н. М. Корнелюк}

Черкаський державний технологічний університет

бул. Шевченка, 460, м. Черкаси, 18000, Україна. E-mail: nkornelyuk@ukr.net

Обгрунтовано необхідність комплексного вивчення основних техногенно змінених складових урбанізованого довкілля, а саме грунтового і рослинного покривів, в умовах інтенсивного розвитку вугільної енергетики, збільшення кількості транспортних засобів та комунікацій. Проаналізовано особливості просторової гетерогенності вмісту важких металів у вегетативних органах (корінь, стебло) діагностичного виду рудеральної рослини Chenopodium album L. та їх рухомих форм у грунтах 24 локалітетів різних функціональних зон м. Черкаси. Встановлена пряма залежність акумулювання ВМ вегетативними органами відповідно до розташування джерел емісії важких металів та сформованих ними геохімічних аномалій. За розрахованим коефіцієнтом біологічного поглинання $\left(К_{\text {Бп }}\right)$, доведено високу біологічну доступність токсикантів техногенного походження $\mathrm{Cu}, \mathrm{Zn}, \mathrm{Pb}, \mathrm{Cd}$ для фітомаси діагностичного виду. Отримані результати $\epsilon$ підтвердженням актуальності розробки експрес-методів щодо моніторингу стану урбосередовища з використанням окремих видів рослин, рослинних угрупувань у якості адекватних біотестерів.

Ключові слова: важкі метали, Chenopodium album L., рудеральна рослинність, техногенне забруднення, грунти, біологічна доступність.

\section{ОСОБЕННОСТИ АККУМУЛИРОВАНИЕ ТЯЖЕЛЫХ МЕТАЛЛОВ ВЕГЕТАТИВНЫХ ОРГАНОВ CHЕNOPODIUM ALBUM L. В УСЛОВИЯХ ТЕХНОГЕННОГО ЗАГРЯЗНЕНИЯ ПОЧВ Г. ЧЕРКАССЫ}

\section{Н. М. Корнелюк}

Черкасский государственный технологический университет

бул. Шевченко, 460, г. Черкассы, 18000, Украина. E-mail: nkornelyuk@ukr.net

Обоснована необходимость комплексного изучения основных техногенно измененных составляющих урбанизированной среды, а именно почвенного и растительного покровов, в условиях интенсивного развития угольной энергетики, увеличения количества транспортных средств и коммуникаций. Проанализированы особенности пространственной гетерогенности содержания тяжелых металлов в вегетативных органах (корень, стебель) диагностического вида рудерального растения Chenopodium album L. и их подвижных форм в почвах 24 локалитетов различных функциональных зон г. Черкассы. Установлена прямая зависимость аккумулирования ТМ вегетативными органами в соответствии с расположением источников эмиссии тяжелых металлов и сформированных ними геохимических аномалий. По рассчитанным коэффициентом биологического поглощения (КБП), доказана высокая биодоступность токсикантов техногенного происхождения $\mathrm{Cu}, \mathrm{Zn}, \mathrm{Pb}, \mathrm{Cd}$ для фитомассы диагностического вида. Полученные результаты являются подтверждением актуальности разработки экспресс-методов для мониторинга состояния урбосереды с использованием отдельных видов растений, растительных сообществ в качестве адекватных биотестеров.

Ключевые слова: тяжелые металлы, Chenopodium album L., рудеральная растительность, техногенное загрязнение, почвы, биологическая доступность.

АКТУАЛЬНІСТЬ РОБОТИ. Швидкі темпи сучасних урбанізаційних процесів та формування промислових агломерацій вимагають розробки та застосування сучасних методів, які б дозволили оцінити екологічний стан різнофункціональних локалітетів урбосистем щодо наслідків імпактного забруднення. В першу чергу це стосується грунтоворослинного покриву, який $\epsilon$ активним депонатором та учасником міграційних процесів хімічних елементів, в тому числі важких металів (далі ВМ).

Однією з головних вимог щодо якості міських грунтів $\epsilon$ забезпечення оптимальних умов існування рослинності у сформованих урбанофітоценозах. За наявності основних елементів живлення у грунтовому покриві, до факторів, що негативно впливають на процеси життєдіяльності рослин належать високі значення pH (7.0 i >), переущільнення грунту, забруднення вуглеводнями, ВМ тощо.

В умовах забруднення грунтів ВМ актуальними $\epsilon$ проблеми, що пов'язані з адаптацією до них живих організмів, особливо рослин, оскільки вони забезпе- чують їх геохімічну функцію та є головними акумуляторами токсикантів [1-3].

При техногенній зміні селитебних ландшафтів відбувається суттєва трансформація рослинного покриву міста, що призводить до уніфікації видів; домінування процесів синантропізації, іяк наслідок переважання чужорідних видів рослин.

3 літературних джерел відомо про особливості та видову специфічність стійкості багаторічних рослин, злаків і овочевих культур до дії забруднюючих речовин [4-8]. Слід зазначити, що накопичення, розподіл і трансформація ВМє недостатньо в вивченими серед типових видів рудеральної рослинності міських екотопів, де значний відсоток становлять однорічники.

Метою роботи було оцінити тенденції накопичення та розподілу $\mathrm{Cu}, \mathrm{Zn}, \mathrm{Pb}, \mathrm{Cd}$ у вегетативних органах Chenopodiumalbum L. локалітетів м. Черкас в залежності від їх концентрації в грунтах, що характеризуються різним ступенем антропогенного навантаження. 
МАТЕРІАЛ I РЕЗУЛЬТАТИ ДОСЛІДЖЕНЬ. Об'єктом досліджень обрано компоненти урбоекосистеми міста: грунт і вегетативні органи (корінь, пагін) трав'янистої рослини $C$. album L. (Amaranthaceae Juss.) - типового представника рудеральної та сегетальної рослинності м. Черкас. Рослину вивчали у генеративному віковому стані (g). За екотопічними особливостями та ступенем антропогенного навантаження територія дослідження включає 24 локалітети (промислові, транспортні, селитебні, рекреаційні зони.). Фонова територія (рекреаційна зона) - вул. Набережна (р-н Соснівка) (рис. 1).

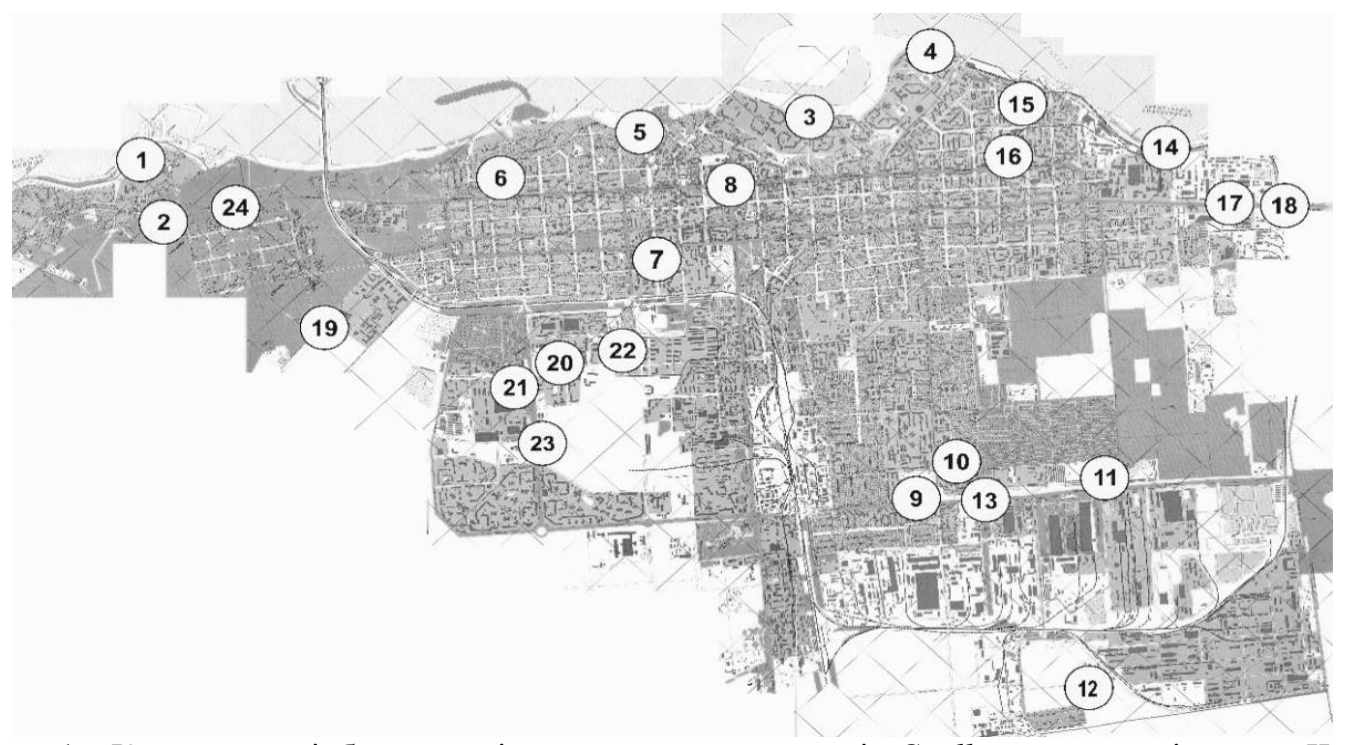

Рисунок 1 - Картосхема відбору грунтів та вегетативних органів C. albumL. у локалітетах м. Черкас 2016-2017 pр: вулиці: 1) Набережна; 2) Канівська; 3) Героїв Дніпра; 4) Козацька; 5) Гагаріна; 6) Хрещатик, (сквер «Дитячий»); 7) Кірова; 8) Б-р Шевченка; 9) Парк Хіміків; 10) вул. Нечуя Левицького; 11) ДП «Черкаська ТЕЦ» ПАТ «Черкаське хімволокно»; 12) ПАТ «Азот»; 13) Проспект Хіміків; 14) вул. Берегова; 15) вул. Чехова;

16) ПАТ «ТЕМП»; 17) ПАТ «Хімреактив»; вулиці: 18) Чигиринська; 19) Якубовського; 20) Акад. Корольова;

21) ПАТ АК «Богдан Моторс»; 22) ПАТ «ЧЗТА»; 23) вул. Сумгаїтська; 24) р-н Соснівка-транспортна магістраль Черкаси - Канів

Вибір досліджуваних металів грунтувався не тільки їх належністю до найпоширеніших урбогенних полютантів, що входять до I та II класів небезпечності: $\mathrm{Zn}, \mathrm{Pb}, \mathrm{Cd}$ (I категорія небезпечності), $\mathrm{Cu}$ (II), але й належність $\mathrm{Cu}, \mathrm{Zn}$ до важливих мікроелементів, а $\mathrm{Cd}, \mathrm{Pb}$, до ультрамікроелементів, що присутні у рослинах та беруть участь у процесах метаболізму [9].

Проби грунту були відібрані з дослідних ділянок відповідно до методичних рекомендацій та діючих стандартів: для грунту - ГОСТ 17.4.3.01-83, ГОСТ 17.4.4.02-84, ДСТУ 4287:2004; для рослин ISO 874 - 2020.

Відібрані зразки аналізувались за вмістом рухомих форм ВМ методом атомно-абсорбційної спектрофотометрії на атомному спектрометрі (CM - 115, M-1, 1989). Вміст рухомих форм ВМ у грунті визначали згідно ДСТУ 4770.1:2007, ДСТУ 4770.9:2007, у рослинних зразках відповідно до методичних рекомендацій з попередньою мінералізацією рослинного матеріалу методом сухого оголення [8].

Ступінь техногенного навантаження на грунтовий покрив та можливість міграційного переходу до рослин визначали шляхом розрахунку основних геохімічних та екологічних показників: коефіцієнту концентрації $\left(K_{\mathrm{C}}\right)$, який характеризує ступінь накопичення ВМ у компонентах урбосистеми відносно фонового зразка та є показником активності радіальної міграції елемента.
Оскільки техногенне забруднення грунтів є багатокомпонентним,коефіцієнт концентрації $\left(K_{\mathrm{C}}\right)$ не $\epsilon$ достатньо інформативним і потребує додаткової інформації щодо токсичного впливу на рослину як окремого металу так і полі елементної їх асоціації. Тому обов'язковою є санітарно-гігієнічна оцінка стану грунтів на основі сумарного показника забруднення - $\left(\mathrm{Z}_{\mathrm{C}}\right)$, що становить адитивну суму перевищень вмісту елементів над їх фоновим рівнем, та характеризує ефект впливу асоціації металів [8, 10-11].

Для визначення доступності рухомих форм металів в грунті для рослини тест-об'єкту та здатності їі вегетативних органів (корінь, пагін) до акумуляції визна-

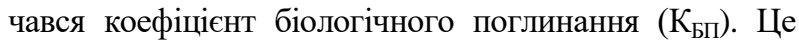
показник, що визначає ступінь використання певного елемента, а також дає можливість оцінити всю систему транслокаційного переходу: грунт - ВМ - (коріння, пагін) однорічна рослина (Б.Б Полинов (1956), О.І Перельман (1966), В.А. Ковда (1975)).

Місто Черкаси (площа 77,6 км² га, населення -

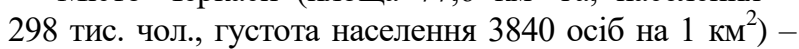
розташоване в межах північно-східного схилу Українського кристалічного щита на високому плесі правого берега р. Дніпро. Забруднення атмосферного повітря міста відбувається за рахунок стаціонарних та пересувних джерел, які розподілені по території міста нерівномірно, що виключає можливість вирішення проблем забруднення як окремих локалітетів так і міста в цілому. Обсяги викидів забруднюючих речовин від стаціонар- 
них джерел складають майже $50 \%$, решта - викиди автомобільного транспорту. Головний внесок у сумарне забруднення повітряного басейну м. Черкас належать підприємствам, що розташовані в межах двох промислових зон (південна і східна технозони). Південна - це територія розташування ПАТ «Азот», ДП «Черкаська ТЕЦ» ПАТ «Черкаське хімволокно», а східна - «Черкаський ДОК», Черкаський лакофарбовий завод. Обсяг валового викиду шкідливих речовин промислових зон становить 95,3 \% від загальної кількості викидів підприємств м. Черкас.

Межу токсичного впливу на рослини конкретного елемента встановити дуже складно, оскільки майже завжди має місце комплексне забруднення, що в свою чергу ускладнює аналіз впливу конкретного металу на рослину або рослинне угрупування.

У відповідності до показників вмісту досліджу- ваних мікроелементів в грунтовому покриві локалітетів м. Черкаси, відносно фонового - вул. Набережна, розраховано коефіцієнт концентрації $\left(\mathrm{K}_{\mathrm{C}}\right)$, який характеризує здатність грунту накопичувати певні елементи, а також відображає активність процесів як вилуговування при $\mathrm{K}_{\mathrm{C}}<1$ так $\mathrm{i}$ нагромадження катіонів металів у зоні кореневої системи при $\mathrm{K}_{\mathrm{C}}>1$.

Для катіонів досліджуваних елементів показник $\mathrm{K}_{\mathrm{C}}$ у зразках грунту усіх локалітетів перевищував одиницю. Значну здатність до накопичення виявили катіони $\mathrm{Cu}^{2+}\left(\mathrm{K}_{\mathrm{C}}=2,6-18,5\right) \mathrm{iZn}^{2+}\left(\mathrm{K}_{\mathrm{C}}=1,1-12,7\right)$, помірну $\mathrm{Pb}^{2+}\left(\mathrm{K}_{\mathrm{C}}=1,4-3,0\right) \mathrm{TaCd}^{2+}\left(\mathrm{K}_{\mathrm{C}}=1,2-2,05\right)$. Відповідно до отриманих результатів дана екологічна оцінка грунту за коефіцієнтом концентрації $\mathrm{K}_{\mathrm{C}}$. Показники досліджених локалітетів характеризують стан грунту як незадовільний $\left(\mathrm{K}_{\mathrm{C}}>5\right)$, задовільний $\left(K_{\mathrm{C}} 3-5\right)$ та нормальний $\left(\mathrm{K}_{\mathrm{C}} 1-2,9\right)$ (рис. 2).

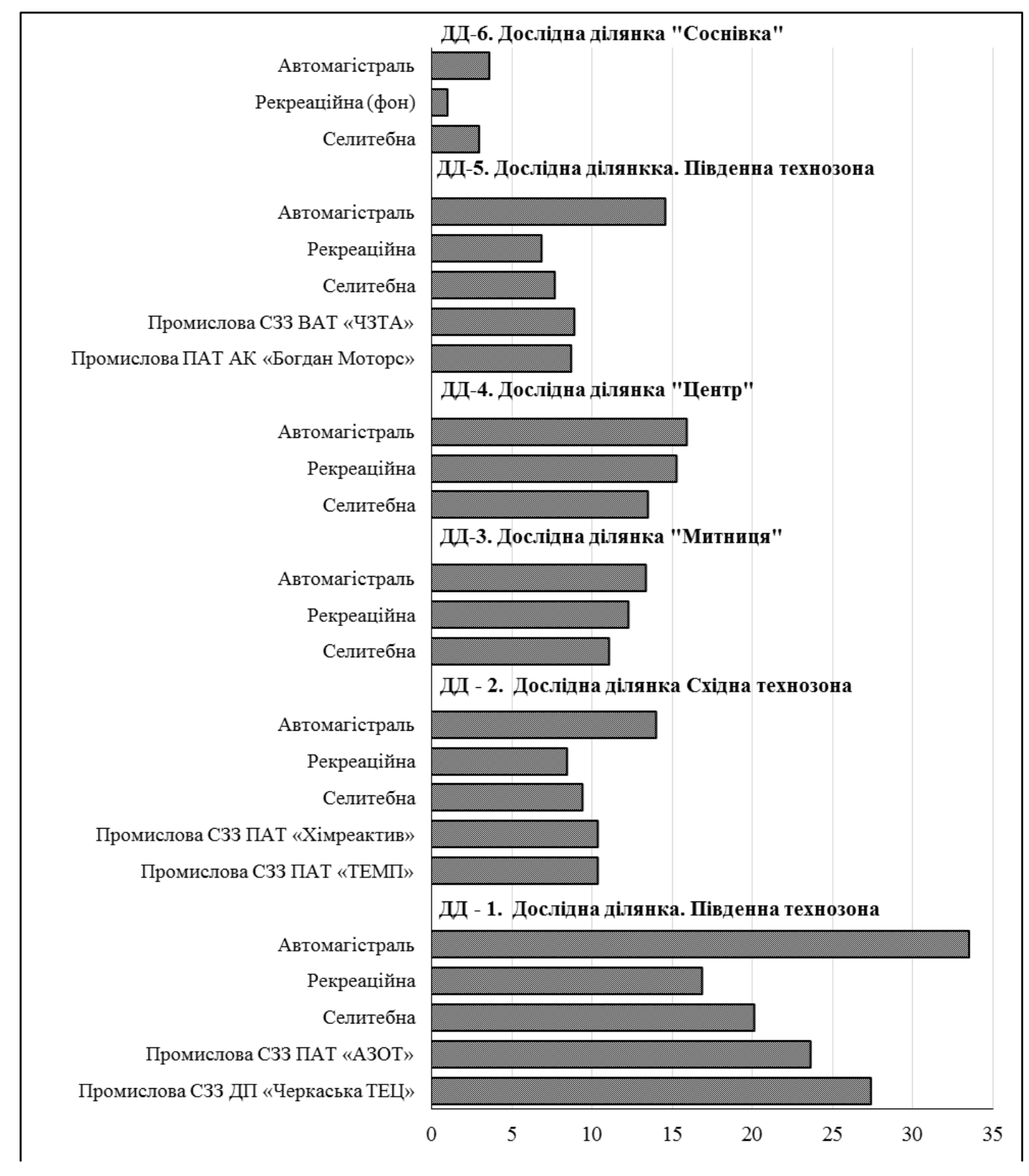

Рисунок 2 - Сумарний показник забруднення $\left(\mathrm{Z}_{\mathrm{C}}\right) \mathrm{BM}$ з локалітетів м. Черкаси 
Коефіцієнт концентрації є не достатньо інформативним показником екологічного стану грунту з огляду на поліелементний характер забруднення. Тому, для екотопів міста Черкаси, з нерівномірним розташуванням джерел забруднення, проведено санітарногігієнічну оцінку стану грунтового покриву на основі розрахунку сумарного показника забруднення $\left(\mathrm{Z}_{\mathrm{C})}\right.$.
За отриманими результатами найбільш несприятлива екологічна ситуація щодо вмісту ВМ у грунтовому покриві сформувалась в межах південної технозони, де утворились $\mathrm{Cu}-\mathrm{Zn}-\mathrm{Pb}-\mathrm{Cd}$ (С33 ДП «Черкаська ТЕЦ», транспортна магістраль проспект Хіміків) та Zn$\mathrm{Cu}-\mathrm{Pb}-\mathrm{Cd}$ геохімічні аномалії (С33 ПАТ «Азот», селитебна, рекреаційна зони). Концентрації ВМ перевищили фонові показники у 1,5 - 15,6 разів ( табл. 1).

Таблиця 1 - Грунтово-геохімічні аномалії вмісту важких металів в грунтах територій дослідних ділянок м. Черкаси

\begin{tabular}{|c|c|c|}
\hline Дослідна ділянка & Зона впливу & Грунтово - геохімічні аномалії \\
\hline 1 & 2 & 3 \\
\hline \multirow{5}{*}{$\begin{array}{c}\text { Південна промзона } \\
\text { (ДД - 1) }\end{array}$} & Промислова СЗ3 ДП «Черкаська ТЕЦ» & $\mathrm{Cu}_{15,6 *}-\mathrm{Zn}_{10,0}-\mathrm{Pb}_{2,6}-\mathrm{Cd}_{2,0}$ \\
\hline & Промислова СЗ3 ПАТ «Азот» & $\mathrm{Zn}_{12,6}-\mathrm{Cu}_{9,2}-\mathrm{Pb}_{2,5}-\mathrm{Cd}_{2,2}$ \\
\hline & Селитебна & $\mathrm{Zn}_{10,5}-\mathrm{Cu}_{9,0}-\mathrm{Pb}_{2,1}-\mathrm{Cd}_{1,5}$ \\
\hline & Рекреаційна & $\mathrm{Zn}_{9,4}-\mathrm{Cu}_{6,6}-\mathrm{Pb}_{2,1}-\mathrm{Cd}_{1,8}$ \\
\hline & Автомагістраль & $\mathrm{Cu}_{18,5}-\mathrm{Zn}_{12,7}-\mathrm{Pb}_{3,0}-\mathrm{Cd}_{2,3}$ \\
\hline \multirow{5}{*}{$\begin{array}{c}\text { Східна промзона } \\
\text { (ДД - 2) }\end{array}$} & Промислова СЗ3 ПАТ «ТЕМП» & $\mathrm{Zn}_{5,0}-\mathrm{Cu}_{4,6}-\mathrm{Pb}_{2,5}-\mathrm{Cd}_{1,3}$ \\
\hline & Промислова СЗ3 ПАТ «Хімреактив» & $\mathrm{Cu}_{6,1}-\mathrm{Zn}_{4,1}-\mathrm{Cd}_{1,7}-\mathrm{Pb}_{1,5}$ \\
\hline & Селитебна & $\mathrm{Cu}_{4,7}-\mathrm{Zn}_{4,4}-\mathrm{Pb}_{1,8}-\mathrm{Cd}_{1,5}$ \\
\hline & Рекреаційна & $\mathrm{Zn}_{4,2}-\mathrm{Cu}_{3,9}-\mathrm{Pb}_{1,9}-\mathrm{Cd}_{1,5}$ \\
\hline & Автомагістраль & $\mathrm{Cu}_{7,2}-\mathrm{Zn}_{5,2}-\mathrm{Pb}_{2,6}-\mathrm{Cd}_{2,0}$ \\
\hline \multirow{3}{*}{$\begin{array}{c}\text { Митниця } \\
\text { (ДД - 3) }\end{array}$} & Селитебна & $\mathrm{Cu}_{6,4}-\mathrm{Zn}_{4,7}-\mathrm{Pb}_{1,8}-\mathrm{Cd}_{1,2}$ \\
\hline & Рекреаційна & $\mathrm{Cu}_{7,4}-\mathrm{Zn}_{4,9}-\mathrm{Pb}_{1,8}-\mathrm{Cd}_{1,2}$ \\
\hline & Автомагістраль & $\mathrm{Cu}_{7,9}-\mathrm{Zn}_{5,1}-\mathrm{Pb}_{1,9}-\mathrm{Cd}_{1,5}$ \\
\hline \multirow{3}{*}{$\begin{array}{c}\text { Центр } \\
\text { (ДД - 4) }\end{array}$} & Селитебна & $\mathrm{Cu}_{8,0}-\mathrm{Zn}_{5,1}-\mathrm{Pb}_{2,1}-\mathrm{Cd}_{1,35}$ \\
\hline & Рекреаційна & $\mathrm{Cu}_{9,1}-\mathrm{Zn}_{5,6}-\mathrm{Pb}_{2,2}-\mathrm{Cd}_{1,4}$ \\
\hline & Автомагістраль & $\mathrm{Cu}_{9,2}-\mathrm{Zn}_{5,6}-\mathrm{Pb}_{2,3}-\mathrm{Cd}_{1,8}$ \\
\hline \multirow{5}{*}{$\begin{array}{c}\text { Південно-західна пром- } \\
\text { зона } \\
\text { (ДД - 5) }\end{array}$} & Промислова ПАТ АК «Богдан Моторс» & $\mathrm{Cu}_{4,5}-\mathrm{Zn}_{3,7}-\mathrm{Pb}_{2,2}-\mathrm{Cd}_{1,3}$ \\
\hline & Промислова СЗ3 ВАТ «ЧЗТА» & $\mathrm{Cu}_{4,8}-\mathrm{Zn}_{2,7}-\mathrm{Pb}_{2,4}-\mathrm{Cd}_{2,0}$ \\
\hline & Селитебна & $\mathrm{Cu}_{4,6}-\mathrm{Pb}_{2,3}-\mathrm{Zn}_{2,3}-\mathrm{Cd}_{1,5}$ \\
\hline & Рекреаційна & $\mathrm{Cu}_{4,5}-\mathrm{Pb}_{2,1}-\mathrm{Zn}_{2,1}-\mathrm{Cd}_{1,2}$ \\
\hline & Автомагістраль & $\mathrm{Cu}_{7,5}-\mathrm{Pb}_{4.9}-\mathrm{Zn}_{2.9}-\mathrm{Cd}_{2,3}$ \\
\hline \multirow{2}{*}{$\begin{array}{c}\text { Північно-західний район } \\
\text { «Соснівка» } \\
\text { (ДД -6) } \\
\end{array}$} & Селитебна & $\mathrm{Cu}_{2,1}-\mathrm{Zn}_{1,4}-\mathrm{Cd}_{1,35}-\mathrm{Pb}_{1,1}$ \\
\hline & Автомагістраль & $\mathrm{Cu}_{2,6}-\mathrm{Cd}_{1,5}-\mathrm{Zn}_{1,4}-\mathrm{Pb}_{1,1}$ \\
\hline
\end{tabular}

\section{* коефіцієнт концентрації}

Найвищі коефіцієнти концентрації та сумарні показники забруднення грунтового покриву м. Черкаси встановлено на території близько 4,6 км ${ }^{2}\left(\mathrm{Z}_{\mathrm{C}}=\right.$ $33,5 ; 23,6 ; 27,4)$, що дозволяє віднести грунти локалітетів південної промзони до сильно та середньо забруднених [8]. Значний вміст ВМ цих локалітетів пов'язаний $з$ викидами Черкаської ТЄЦ, перекриттям ореолів розсіювання викидів ТЄЦ та пересувних джерел при несприятливому вітровому режимі. Стан грунтового покриву центральної частини міста (рис. 2, табл. 1) за вмістом ВМ, концентрація яких перевищила фонові показники у 1,2 - 9,2 рази 3 утворенням $\mathrm{Cu}-\mathrm{Zn}-\mathrm{Pb}-\mathrm{Cd}$ геохімічної аномалії, характеризується як «середньо забруднений», інтервал сумарного показника забруднення становив $\left(\mathrm{Z}_{\mathrm{C}}=11,9-16,9\right)$.

Для східної промзони з утворенням $\mathrm{Zn}-\mathrm{Cu}-\mathrm{Pb}$ - $\mathrm{Cd}$ (СЗ3 ПАТ «ТЕМП»), $\mathrm{Cu}-\mathrm{Zn}-\mathrm{Cd}-\mathrm{Pb}$ (С33 ПАТ «Хімреактив»), $\mathrm{Cu}-\mathrm{Zn}-\mathrm{Pb}-\mathrm{Cd}$ геохімічних аномалій, вміст доступних форм ВМ перевищив фонові показники у 1,3 - 7,2 рази. Інтервал сумарного показника хімічного забруднення становив $\left(Z_{\mathrm{C}}=8,5-14,3\right)$, що дозволяе віднести грунтовий покрив до категорії - «слабко забруднених» (рис 2, табл. 1).
Грунтовий покрив північно-західної частини міста району «Перемоги» має перевищення фонових показників ВМ у 1,3 - 7,5 рази. У даному районі сформувались $\mathrm{Cu}-\mathrm{Zn}-\mathrm{Pb}-\mathrm{Cd}$ та $\mathrm{Cu}-\mathrm{Pb}-\mathrm{Zn}-\mathrm{Cd}$ геохімічні аномалії. У відповідності до показника хімічного забруднення $\left(\mathrm{Z}_{\mathrm{C}}=7,7-14,6\right)$ територію віднесли до категорії - «слабко забруднених» ( табл. 1).

Слід зазначити, що грунтовий покрив локалітетів на території яких відсутні стаціонарні джерела забруднення має тенденцію наближення до категорії «середньо забруднених», що пов'язано 3 емісіями промислових об'єктів південної та східної технозон при несприятливому вітровому режимі, підсиленому транспортним навантаженням, незадовільним технічним станом транспортних засобів, застарілою пропускною здатністю транспортних розв'язок міста.

Формуванню $\mathrm{Cu}-\mathrm{Pb}-\mathrm{Zn}-\mathrm{Cd}$ геохімічної аномалії трансформованого ландшафту вздовж автомагістралі Черкаси-Канів північно-західного району «Соснівка», сприяв інтенсивний рух автотранспорту, що забезпечує міжміські та міжрегіональні транспортні перевезення. Вміст ВМ перевищив фонові показники у 1,1 - 2,6 рази. За значенням сумарного показника хімічного забруднення $\left(Z_{C}=3,0,3,6\right)$ ця територія віднесена до категорії«умовно чисті» (див. рис.1, табл. 1). 
Визначення доступності металів в грунті для однорічної рудеральної рослини лободи білої (Chenopodiumalbum L.) локалітетів м. Черкаси та здатності до їх акумуляції проводилось з застосуванням коефіцієнту біологічного поглинання $\left(\mathrm{K}_{\text {БП }}\right)$ для фітомаси надземної і підземної фракцій тестоб'єкта (рис. 3-4).

Розрахований коефіцієнт біологічного поглинання для коріння свідчать про значну доступність та високу здатність до акумулювання ВМ корінням в ряду: $\mathrm{Cd}>\mathrm{Pb}>\mathrm{Zn}>\mathrm{Cu}$ (рис.3). Показник $\mathrm{K}_{\text {БП }}>1$ локалітетів з інтенсивним впливом техногенного фактору (санітарно-захисні зони, транспортні розв'язки) свідчать про активний транслокаційний перехід мікроелементів 3 грунту в коріння.

Щодо надземної фіто маси C. album L. отримані результати свідчать про накопичення пагонами $\mathrm{Cu}$ i $\mathrm{Cd}$ у 1,2 - 1,5 рази більше ніж корінням. Найбільші коефіцієнти встановлено для санітарно-захисних зон та при магістральних локалітетів.

Для $\mathrm{Zn}, \mathrm{Pb}$ встановлено збільшення вмісту і відповідно коефіцієнту біологічного поглинання надземної фітомаси до підземної у 0,8-1,2 рази на територіях, що належать С33 та транспортним магістралям (рис. 4).

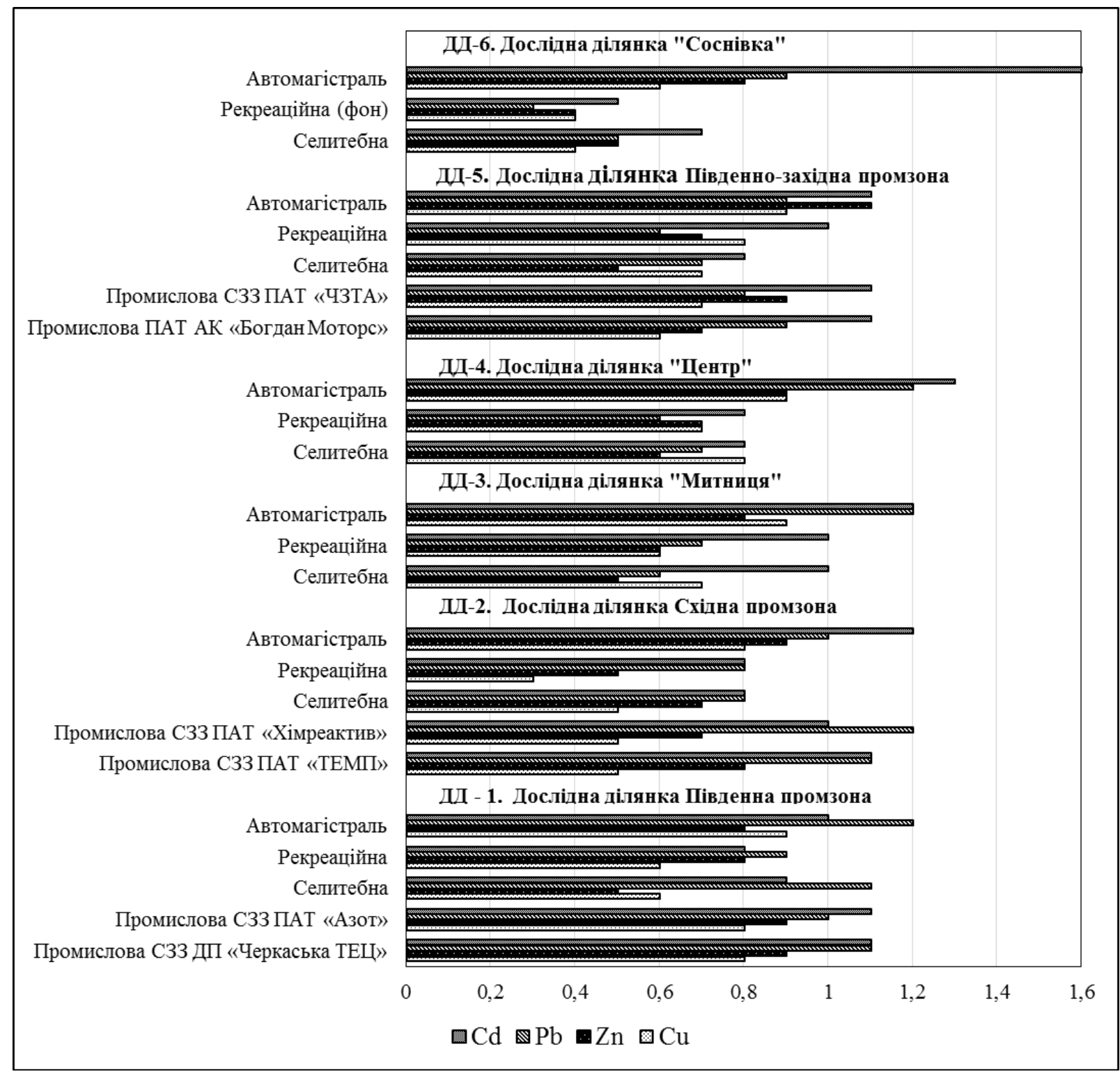

Рисунок 3 - Значення коефіцієнту біологічного поглинання $\left(\mathrm{K}_{\text {Бп }}\right)$ : транслокаційний перехід - рухомі форми ВМ

в грунті та коріння C. album L. (мг/кг сухої маси) з локалітетів м. Черкас 


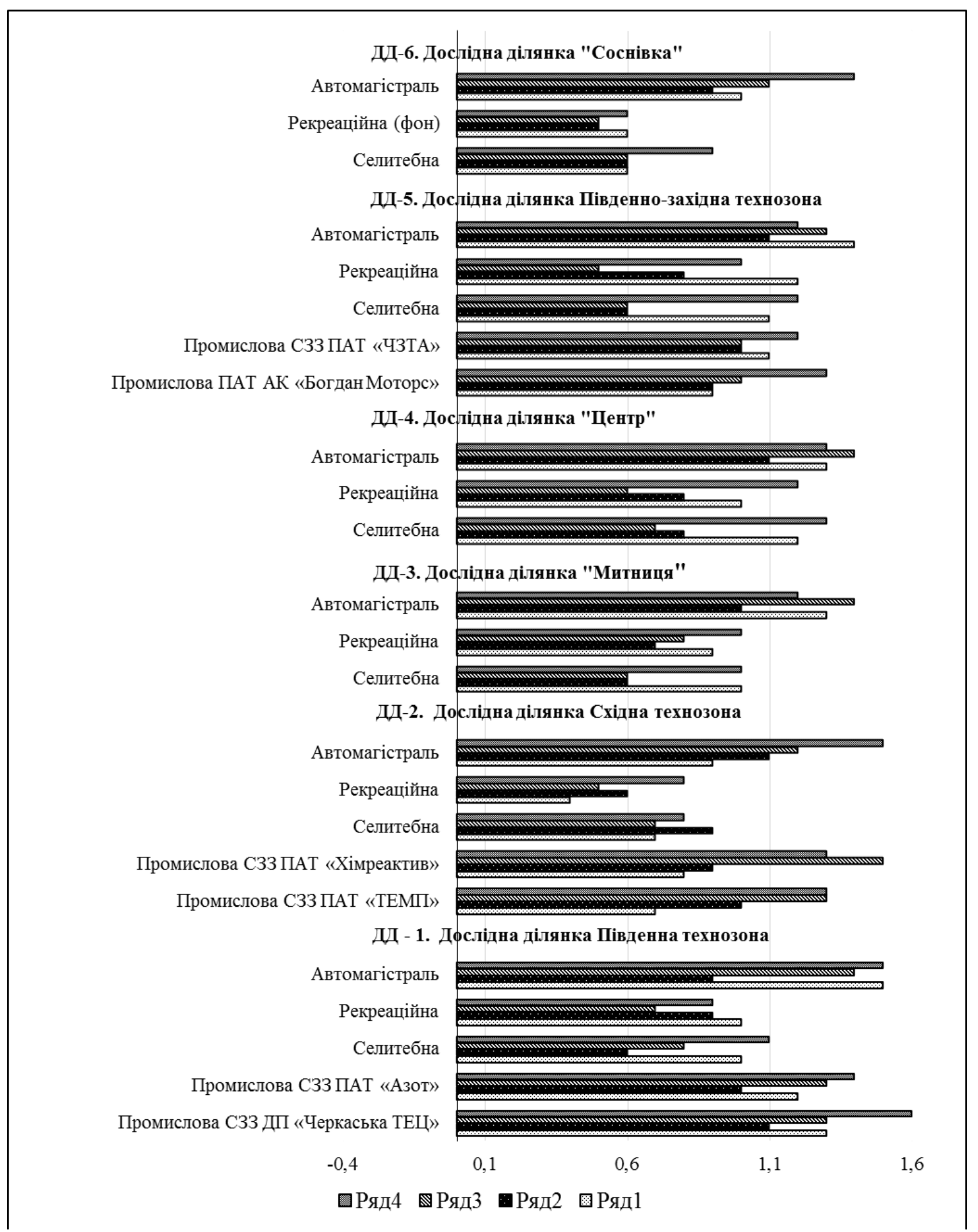

Рисунок 4 - Значення коефіцієнту біологічного поглинання $\left(K_{\text {Бп }}\right)$ : транслокаційний перехід- рухомі форми ВМ

в грунті та пагоні $C$. albumL.(мг/кг сухої маси) 3 локалітетів м. Черкас

ВИСНОВКИ. 1. Особливості розподілу концентрацій ВМ у грунтах визначається характером та інтенсивністю дії антропогенного фактору. Максимальні концентрації ВМ встановлено у локалітетах примагістральних шляхів та санітарно захисних зон.

2. В межах урбосистеми міста виділено локалітети $\mathrm{BM}$ які мають $\mathrm{K}_{\mathrm{C}}>1 \mathrm{i}$ активно акумулюються у зоні кореневої активності рослин.

3. За сумарним показником забруднення ВМ грунтовий покрив південної промзониналежить до сильно та середньо забруднених $\left(\mathrm{Z}_{\mathrm{C}}=33,5 ; 23,6\right.$;
27,4). Решту локалітетів віднесли до категорії «слабко забруднених», але на територіях де відсутні виробничі потужності спостерігається тенденція наближення до категорії «середньо забруднених», що пов'язано 3 емісіями промислових об'єктів південної та східної промзон, несприятливому вітровому режимі, підсиленому транспортним навантаженням, незадовільним технічним станом транспортних засобів, застарілою пропускною здатністю транспортних розв'язок міста. 
4. Отримані коефіціснти концентрації дають можливість встановити ступінь нагромадження рухомих форм потенційно небезпечних полютантів у корененасичених шарах грунту та їхньої здатності до транслокаційного переходу: грунт - вегетативні органи.

5. Здійснено порівняння техногенного забруднення грунту та можливість переходу ВМ до рослинної фітомасив антропогенно змінених локалітетах.

6. Показано, що незалежно від локалітетів спостерігається позитивна динаміка збільшення К БП ВМ у вегетативних органах (корінь, пагін) C. album L., що свідчить про високу ступінь доступності елементів та здатність рослини їх акумулювати.

7. Виявлена пряма залежність накопичення ВМ тест-об'єктом у відповідності до розташування джерел емісії та утворених геохімічних аномалій у грунтах м. Черкас.

\section{ЛІТЕРАТУРА}

1. Біоіндикація техногенного забруднення м. Києва: методичні підходи: монографія / за ред. О. П. Дмітрієва. Київ: Наш формат, 2016. 122 с.

2. Degórska A. An assessment of urban habitat contamination with selected heavy metals within the city of Katowice using the common dandelion (Taraxacum officinale Web.) as a bioindicator. Environmentaland Sosio-economic Studits. 2013.1(4). P. 29-40.

3. Scheffer K., W. Stach., Vardakis F. Überdie Verteilungder Schwermetallen Eisen, Mangan, Kupherund, and Zinkin is Sommergesternpflanzen. Landwirtsch, Forsch, 1979. 326 p.

4. Memon A. R., Aktoprakligil D., Ozdemir A. Heavy Metal Accumulation and Detoxification
Mechanismsin Plants. Turk J Bot. 2001. Vol. 25 P. 111-121.

5. Cobbett C. S. Phytochelatins and Their Rolesin Heavy Metal Detoxification. Plant Physiology. 2000. Vol. 123. P. 825-832.

6. Eltrop L., Brown G., Joachimet O. Leadtolerance of Betula and Salixin the miningarea of Mechernich (Germany). Plant and Soil. 1991. V. 131. P. 275-285.

7. Корнелюк Н. М., Конякін С. М., Гродзинська Г. А. Вміст важких металів у листках Tilia cordata Mill. та грунті урбоекосистем м. Черкаси Агроекологічний журнал. 2016. № 3. С. 24-32.

8. Корнелюк Н. М., Мислюк О. О. Природні і антропогенні фактори аеротехногенного забруднення м. Черкаси важкими металами. Вісник наџіонального університету «Львівська політехніка». 2007. № 590. C. 260-269.

9. Заєць Р. А., Ковальов А. І., Бужин О. А., Джулай О. С. Оцінка рівня забруднення атмосферного повітря міста Черкаси. Вісник Кременчуцького національного університету імені Михайла Остроградського. 2016. 2 (97), С. 109-112.

10. Мислюк О. О., Корнелюк Н. М. Екологічні аспекти функціонування Черкаської ТЕЦ. Вісник Кременчуиького національного університету імені Михайла Остроградського. 2008. 1 (48), С. 111-115.

11. Маджд С. М., Бовсуновский Е. О., Тагачинська О. В. Наукові методи контролю якості грунтів як індикатора екологічної небезпеки на техногенно навантажених територіях. Екологічна безпека. Кременчук: КрНУ, 2016. Вип. 2 (97). С. 65-69.

\section{ACCUMULATION OF HEAVY METALS IN CHENOPODIUM ALBUM L. VEGETATIVE BODIES IN THE CONDITIONS OF TECHNOGENIC POLLUTION OF SOILS OF CHERKASSY CITY}

\section{N. Kornelyuk}

Cherkasy State Technological University

vul. Shevchenka, 460, Cherkasy, 18000, Ukraine. E-mail:nkornelyuk@ukr.net.

Purpose. In the conditions of intensive development of industry, coal energy, transport communications, active chemicalization of agriculture, there is a sharp increase in environmental pollution, namely its main components of soil and vegetation. Modern requirements for assessing the quality of the environment should first of all be focused on biotic indicators. Analysis of the content of heavy metals in soils and plants is a significant component of the monitoring of the urban environment caused by technological activities of people. The conducted studies provide an opportunity to estimate the accumulation and distribution trends of $\mathrm{Cu}, \mathrm{Zn}, \mathrm{Pb}, \mathrm{Cd}$ in the vegetative organs of the Chenopodium album L. localities of Cherkassy city, depending on their concentration in soils, characterized by different degrees of anthropogenic loading Methodology. To determine the features of accumulation of heavy metals by vegetative organs of Shenopodium album L. in the conditions of technogenic pollution of soils, methods of physio-chemical analysis were used. Determination of the content of the mobile form of heavy metals in soils and vegetative mass was analyzed by the atomic absorption method. The degree of technogenic loading on the soil cover and the possibility of migratory transition to plants were determined by calculating the basic geochemical and environmental indicators $\left(\mathrm{K}_{\mathrm{C}}\right.$ - concentration factor, $Z_{c}$ - total pollution index). Results.The analysis of the technogenic contamination of soils and the possibility of the transfer of heavy metals to plant phytomass from 24 localities in Cherkassy is carried out. Originality. The dynamics of the increase in the heavy metal biologic absorption coefficient in the vegetative organs of the Chenopodium album L. (root, shoot) is established, which indicates the high degree of availability of the elements and the ability of the plants to accumulate them. Practical value. The dependence of the accumulation of heavy metals by the test object in the location of emission sources and geochemical anomalies in the soil of urban ecosystems is revealed. Conclusions. With regard to the concentration coefficient, the degree of accumulation of mobile forms of hazardous contaminants in root-saturated soil layers and their ability to translate the transition in a row can be established: soilvegetative organs.

Key words: heavy metals, Chenopodium album L., ruderal vegetation, technogenic pollution. 


\section{REFERENCES}

1. Bioindykatsiya tekhnohennoho zabrudnennia mista Kyeva: metodychni pidkhody [Bioindication of technogenic pollution in Kiev: methodical approaches]. O.P. Dmitriev (Ed.). Kyiv: Nash format, 2016. (in Ukrainian).

2. Degórska, A. (2013). An assessment of urban habitat contamination with selected heavy metals within the city of Katowice using the common dandelion ( $\mathrm{Ta}$ raxacum officinale Web.) as a bioindicator. Environmental and Sosio-economic Studits. 1 (4), pp. 29-40. (in English).

3. Scheffer, K., Stach, W., Vardakis, F. (1979). Über die Verteilung der SchwermetallenEisen. Mangan, Kupher und Zink in Sommergesternpflanzen. Landwirtsch, Forsch, 326 p. (in German).

4. Memon, A. R., Aktoprakligil, D., Ozdemir, A., Vertii, A. (2001). Heavy Metal Accumulation and Detoxification Mechanisms in Plants. Turk J Bot., Vol. 25, pp. 111-121. (in English).

5. Cobbett, C. S. (2000). Phytochelatins and Their Roles in Heavy Metal Detoxification. Plant Physiology, Vol. 123, pp. 825-832. (in English).

6. Eltrop, L., Brown, G., Joachim, O., Brinkmann, K. (1991). Lead tolerance of Betula and Salix in the mining area of Mechernich (Germany). Plant and Soil., V. 131, pp. 275-285. (in English).

7. Korneliuk, N., Koniakin, S., Hrodzynska, A. (2016). Vmist vazhkykh metaliv u lystkakh Tilia cordata Mill. ta grunti urboekosystem $m$. Cherkasy [The content of heavy metals in the leaves of Tilia cordata Mill. and in the soils of urban ecosystems of Cherkasy city. Ahroekolohichnyy zhurnal [Agroecological journal], No. 3. - pp. 24-32. (in Ukraine).
8. Korneliuk, N. M., Mysliuk, O. O. (2007). Pryrodni $i$ antropohenni factory aerotekhnohennoho zabrudnennya $m$. Cherkassy vazhkymy metalamy [Natural and anthropogenic factors of airtechnical pollution of Cherkassy sity by heavy metals].Visnyk natsionalnoho universytetu «Lvivska politekhnika» [Bulletin of the National University «Lviv Polytechnic»), No 590, pp. 260-269. (in Ukrainian).

9. Zaiets, R., Kovaliov, A., Buzhyn, O., Dzylai, O. (2016). Otsinka rivnya zabrudnennya atmosfernoho povitryamista Cherkassy [Assessment of air pollution level of Cherkassy sity]. Visnyk Kremenchuts'koho derzhavnoho politekhnichnoho universytetu imeni $M$. Ostrohradskoho [Bulletin of Kremenchuk Mykhailo Ostohradskyi State Polytechnic University]. Vol. 2 (97), Iss.1, pp. 109-112. (in Ukraine).

10. Mysliuk, O. O., Korneliuk, N. M. (2008). Ekolo-hichni aspekty funktsionuvannya Cherkaskoyi TETS [Environmental aspects functioning of Cherkassy Heat Power Station]. Visnyk Kremenchuts'koho derzhavnoho politekhnichnoho universytetu imeni $M$. Ostrohradskoho [Transactions of Kremenchuk Mykhailo Ostohradskyi State Polytechnic University], Iss.1 (48), Vol.1, pp. 111-115. (in Ukraine).

11. Madzhd, S. M., Bovsunovskyy, E. O., Tagachinska, O. V. (2016). Naukovi metody kontrolyu yakosti gruntiv yak indykatora ekolohichnoyi nebezpeky na tekhnohennonavantazhenykh terytoriyakh [Quality control of soils as indicators of environmental hazards of urban areas by scientific methods]. Visnyk Kremenchuts'koho derzhavnoho politekhnichnoho universytetu imeni $M$. Ostrohradskoho [Bulletin of Kremenchuk Mykhailo Ostohradskyi State Polytechnic University]. Vol. 2 (97), pp. 65-69. (in Ukraine).

Стаття надійшла 01.04.2019. 